\title{
Antarctic bryophyte research-current state and future directions
}

\author{
PAULO E.A.S. CÂMARA ${ }^{1}$, MICHELINE CARVALHO-SILVA ${ }^{1} \&$ MICHAEL STECH ${ }^{2,3}$ \\ ${ }^{1}$ Departamento de Botânica, Universidade de Brasília, Brazil UnB; \\ झ"paducamara@gmail.com; 이ttp://orcid.org/0000-0002-3944-996X \\ ="silvamicheline@gmail.com; @ https://orcid.org/0000-0002-2389-3804 \\ ${ }^{2}$ Naturalis Biodiversity Center, P.O. Box 9517, 2300 RA Leiden, Netherlands; \\ ${ }^{3}$ Leiden University, Leiden, Netherlands

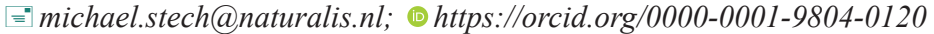

\begin{abstract}
Botany is one of the oldest sciences done south of parallel $60^{\circ} \mathrm{S}$, although few professional botanists have dedicated themselves to investigating the Antarctic bryoflora. After the publications of liverwort and moss floras in 2000 and 2008 , respectively, new species were described. Currently, the Antarctic bryoflora comprises 28 liverwort and 116 moss species. Furthermore, Antarctic bryology has entered a new phase characterized by the use of molecular tools, in particular DNA sequencing. Although the molecular studies of Antarctic bryophytes have focused exclusively on mosses, molecular data (fingerprinting data and/or DNA sequences) have already been published for $36 \%$ of the Antarctic moss species. In this paper we review the current state of Antarctic bryological research, focusing on molecular studies and conservation, and discuss future questions of Antarctic bryology in the light of global challenges.
\end{abstract}

Keywords: Antarctic flora, conservation, future challenges, molecular phylogenetics, phylogeography

\section{Introduction}

The Antarctic is the most pristine, but also most extreme region on Earth in terms of environmental conditions. It is geopolitically defined as comprising all lands and waters south of $60^{\circ} \mathrm{S}$, and can be biogeographically divided into the Maritime Antarctic zone and the Continental Antarctic zone (Ochyra et al. 2008).

Antarctica is currently administered by the Antarctic Treaty and related agreements (Antarctic Treaty System). In 1959, twelve countries originally signed the Treaty, banning the commercial and military use of Antarctica as well as nuclear tests and garbage disposal. The importance of protecting the Antarctic environment was reinforced by the Protocol on Environmental Protection to the Antarctic Treaty (Madrid Protocol) in 1998. The Antarctic Treaty also clearly states that a country has to demonstrate its interest in the region by means of performing significant scientific research in order to achieve a consultative status, i.e. having voting rights over the region.

Antarctic scientific research is organized in different ways by the consultative members, e.g. by Antarctic Institutes (e.g. Argentina, Chile), Antarctic programs (e.g. Australia, Brazil, UK), or as part of polar programs (e.g. Netherlands). To date, 29 of the 54 countries that are party to the Treaty have a consultative status and, together with three further countries, run research facilities in Antarctica (operated during summer only or year-round). To manage the complex and expensive logistics in Antarctica, some countries rely on military support (e.g. Brazil, Chile), invest in civilian research vessels (e.g. UK, Germany) or a mix of both (e.g. Spain). Predominant research fields, such as geology, glaciology, oceanography, marine and terrestrial biology, differ between countries, but very few have focused on Antarctic vegetation, in particular bryophytes.

Only $0,18 \%$ of the Antarctic terrestrial area is ice-free in summer (Burton-Johnson et al. 2016), and the extreme climatic conditions and low diversity of substrates (mostly rock, soil, bones) severely limit the formation of (vascular plant) vegetation. In the Maritime Antarctic, which south of $60{ }^{\circ} \mathrm{S}$ comprises the archipelagoes of the South Shetland Is. and South Orkney Is. as well as parts of the west coast of the Antarctic Peninsula, conditions are less severe, and the vegetation is more diverse and abundant than in the much harsher Continental Antarctic with only 24 species (Ochyra et al. 2008). In the latter, bryophytes can be found, e.g. in melt pools and streams, in rock fissures, and on geothermal 
ground, which is one of the main habitats for Antarctic liverworts (Bednarek-Ochyra et al. 2000). However, some ice-free areas of Continental Antarctica are near the cold-arid limit for life, where bryophytes only survive as part of hypolithic communities associated with the underside of translucent quartz rocks (Khan et al. 2011).

While overall plant diversity decreases with increasing latitude, the relative diversity of bryophytes compared to vascular plants increases in the polar regions, most drastically so in the Antarctic. In contrast to only two native flowering plants, Deschampsia antarctica E.Desvaux (1854: 338) (Antarctic hairgrass, Poaceae) and Colobanthus quitensis (Kunth 1823: 19) Bartling (1831: 13) (Caryophyllaceae) as well as one invasive grass (Poa annua L. 1753: 68), 116 species of mosses (Ochyra et al. 2008; Ellis et al. 2013a, 2013b; Sollman 2015; Câmara et al. 2019a) and 28 species of liverworts (Bednarek-Ochyra et al. 2000, Suárez et al. 2019) are recorded from Antarctica, which form a major component of the Antarctic terrestrial vegetation.

The history of Antarctic bryology as well as problems and advances of bryological research in Antarctica have previously been discussed by Greene $(1964,1967)$, Ando (1979) and Seppelt et al. (1998). Thereafter, Ochyra et al. (2008) updated and extended the knowledge on the Antarctic moss flora in terms of botanical history, taxonomy and biogeography, including early molecular data based on DNA fingerprinting. Since then, phylogenetic reconstructions from DNA sequences have had a considerable impact on our understanding of polar bryophyte diversity. Most recently, Câmara \& Carvalho-Silva (2020) published an overview on botanical research in Antarctica, focusing on the role of Brazil.

The polar regions face the accelerating threats of global climate change. As Lewis et al. (2017a) discussed for the Arctic, the development of strategies for ecosystem conservation and management in the face of climate change is hindered by knowledge gaps in Arctic bryology. Since this may be true for the Antarctic as well, here we present an update on the current state of Antarctic bryological research, focusing on molecular studies and conservation, and discuss future research questions of Antarctic bryology in the light of global challenges.

\section{Antarctic bryophyte diversity-Recent history and current state of knowledge}

The 'classical' knowledge on the taxonomy and species diversity of Antarctic bryophytes is largely based on the collections and scientific work of relatively few professional botanists, taxonomists and ecologists, starting from Joseph Dalton Hooker, more than 180 years ago, and later especially Stanley Greene (1928-1989), Royce Longton, Ronald I. Lewis Smith, Rod Seppelt, Ryszard Ochyra, Halina Bednarek-Ochyra, and Peter Convey. Many years of collecting and taxonomic work resulted in the comprehensive Illustrated Moss Flora of Antarctica (Ochyra et al. 2008), which serves as main reference for the Antarctic moss flora. Less attention has been given to the Antarctic liverwort flora, despite the likewise important publication The Liverwort Flora of Antarctica (Bednarek-Ochyra et al. 2000). Liverworts are not only less diverse in Antarctica, they can also be more easily missed during field collecting than many moss species, due to their small size and stems growing intermingled with mosses.

The knowledge comprised in Bednarek-Ochyra et al. (2000) and Ochyra et al. (2008) may suggest that little remains to be studied about the Antarctic bryophyte flora. On the contrary, the knowledge from these two atlases form a foundation for addressing remaining taxonomic problems and interpret new results from floristic and taxonomic studies (e.g. Li et al. 2009; Kurbatova \& Ochyra 2012; Ellis et al. 2013a, 2013b; Sollman 2015; Suárez et al. 2019), and especially molecular studies, considering that both books were published before the more intensive use of DNA sequence data from Antarctic bryophytes.

The use of molecular tools to study Antarctic bryophyte diversity started in the 1990's, initially applying isozymes (Melick et al.1994) or isozymes together with Random Amplified Polymorphic DNA (RAPD) fingerprinting (Adam et al. 1997). The latter technique was extensively used in a number of papers by Australian researchers P. M. Selkirk, M. L. Skotnicki and collaborators (Dale et al. 1999; Selkirk et al. 1997, 1998; Skotnicki et al. 1997, 1998a, 1998b, 1998c, 1999a, 1999b, 2000, 2001, 2002, 2004a, 2004b). Skotnicki et al. (2000) summarized the inferences made from RAPD analysis until then. They concluded that the method was suitable to infer population-level genetic diversity, analyse dispersal patterns, such as long-distance dispersal events by air and localized dispersal by meltwater streams in several moss species, and identify unknown plant material such as moss protonema. Subsequent studies (partly combining RAPD and ITS sequence data) indicated, for example, single colonization events of moss populations on isolated geothermal grounds in Continental Antarctica (Skotnicki et al. 2001, 2002). The high levels of genetic diversity within moss colonies, as observed in the RAPD studies, were initially ascribed mainly to mutagenesis (Skotnicki et al. 2000, 2004b). However, it was revealed that RAPD studies had incorrectly reported high levels of genetic diversity, likely 
due to contaminants (Stevens et al. 2007), and the RAPD method has not been used for Antarctic mosses ever since. In fact, microsatellite data revealed that Ceratodon purpureus (Hedwig 1801: 36) Bridel (1826: 480) populations from Continental Antarctica display less intra-population genetic diversity than populations from temperate and subAntarctic sites, as opposed to RAPD data (Clarke et al. 2008, 2009). Populations of Sanionia uncinata (Hedwig (1801: 289) Loeske (1907: 309) showed similar or lower mean values for intra-population genetic diversity as other, non-Antarctic moss species based on Amplified Fragment Length Polymorphism (AFLP) fingerprinting (Hebel et al. 2018).

The nuclear ribosomal internal transcribed spacer (nrITS) region became the first DNA sequence marker to be used in Antarctic bryophytes, either together with RAPD (Skotnicki et al. 2002, 2004a, 2004b; Stevens et al. 2007), as a single marker (Skotnicki et al. 2005, 2012; Pisa et al. 2014; Biersma et al. 2018a), together with other nuclear markers (phy2: Hills et al. 2010; 18S: Khan et al. 2011; Liu et al. 2014), or, most frequently, in combination with one or more chloroplast markers (Hedenäs 2012; Kato et al. 2013; Biersma et al. 2017, 2018b, 2020; Rankin et al. 2017; Saługa et al. 2018; Câmara et al. 2019a, 2019b; Zaccara et al. 2020). Most frequently sequenced chloroplast markers were $\operatorname{trn} \mathrm{L}-t r n \mathrm{~F}$ and $t r n \mathrm{~S}-r p s 4$, followed by $r p l 16, a t p \mathrm{~B}-r b c \mathrm{~L}, \operatorname{trn} \mathrm{G}$, and $a t p \mathrm{H}-a t p \mathrm{I}$ (see Stech \& Quandt 2010 for detailed descriptions of these markers, except atpH-atpI which has only rarely been used for bryophytes, starting with Piñeiro et al. 2012).

The 'DNA sequence era' is characterized by a diversification in terms of research groups and institutions (including the authors of this review), participation of a new generation of scientists contributing to study Antarctic bryophyte diversity, and broader research aims and geographic focus in many studies. Studies on global phylogeographic patterns focused on cosmopolitan species (Bryum argenteum Hedwig (1801: 181), Pisa et al. 2014; Zaccara et al. 2020; Ceratodon purpureus, Biersma et al. 2020) and especially on bipolar species. Bipolarity, i.e., species with occurrence in both polar (Arctic and Antarctic) and cool-temperate regions, with or without intermediate occurrences in tropical mountain areas, is quite a common phenomenon in Antarctica, with about $45 \%$ of its flora being bipolar, including some of the most common species (Ochyra et al. 2008). Recent molecular phylogenetic analyses supported the monophyly of a number of bipolar moss species (Polytrichastrum alpinum (Hedwig 1801: 92) G.L. Smith (1971: 37) and three species of Polytrichum Hedwig (1801: 88), Biersma et al. 2017; Schistidium rivulare (Bridel 1801: 276) Podp., Biersma et al. 2018a) and suggested a Holarctic origin for all of them except Polytrichum juniperinum Hedwig (1801: 89), (Biersma et al. 2017). In Sanionia Loeske (1907: 309) (Hedenäs 2012), the (molecular) species delimitations were less clear, but Northern Hemisphere origins of Southern Hemisphere populations of the bipolar $S$. uncinata were inferred as well. A corresponding pattern of Northern Hemisphere origins of sub-Antarctic populations was observed in the bipolar Cinclidium stygium Swartz (1803: 27) (Piñeiro et al. 2012) and Tetraplodon fuegianus Bescherelle (1885: 64) (Lewis et al. 2017b). Another important phylogeographic inference based on molecular data of the cosmopolitan or bipolar species was that the contemporary Antarctic moss flora is a mix of both relictual survivors of the last glacial maximum and recent colonists from multiple long-range dispersal events (Pisa et al. 2014; Biersma et al. 2017, 2018a, 2018b, 2020). In Ceratodon purpureus, both an ancient Antarctic clade as well as several genotypes more recently introduced in Antarctica were observed (Biersma et al. 2020). Different inferences were made concerning connectivity within Antarctica. For example, Biersma et al. (2018a) suggested that the mountainous spine on the Antarctic Peninsula forms a strong barrier to gene flow in Schistidium antarctici (Cardot 1906: 15) L.I.Savicz \& Smirnova (1965: 252), whereas Zaccara et al. (2020) inferred strong connectivity and the existence of intra-Antarctic dispersal routes for Bryum argenteum.

As mentioned before, bryophyte plants in the Antarctic grow under extreme environmental conditions, and consequently are very difficult to identify by a traditional morphological approach. DNA sequencing has proven a powerful tool for species identification as well as to understand species delimitations and relationships. Molecular species identification (DNA barcoding) has been applied to mosses in aquatic (Antarctic lakes, Kato et al. 2013; Rankin et al. 2014), terrestrial (Liu et al. 2014) and saxicolous (Khan et al. 2011) habitats.

Phylogenetic analyses and the use of a molecular species delimitation method (Automatic Barcode Gap Discovery, ABGD; Puillandre et al., 2012) provided additional insights into Antarctic Schistidium Bruch \& Schimper (1845: 1) (Biersma et al. 2018a) and Bartramia Hedwig (1801: 164) (Câmara et al. 2019a), including a potential new species of Schistidium in South Georgia and southern Chile (Biersma et al. 2018a) and Bartramia subsymmetrica Cardot (1906: 8) new to Antarctica (Livingston Island; Câmara et al. 2019a). However, ABGD may also tend to overlump species compared to phylogenetic analysis, as observed in Bartramia (Câmara et al. 2019a), and further comparative analyses of automated species delimitation methods may be needed. Furthermore, analyses of molecular variation have allowed for a better understanding of the effects of such extreme environmental conditions on morphological plasticity (Câmara et al. 2018b). 
At higher taxonomic levels, the application of DNA tools resulted in separating the bipolar species Hypnum revolutum (Mitten 1859: 97) Lindberg (1866: 542) in a new moss genus (Roaldia P.E.A.S. Câmara \& Carvalho-Silva 2018: 257) and its transfer from Hypnaceae Schimper (1856: 113) to Pylaisiaceae Schimper (1860: 518) (Câmara et al. 2018). Taxonomic changes from phylogenetic studies not addressing Antarctic species directly impact on the family composition of the Antarctic moss flora as well. Compared to Ochyra et al. (2008), these include transfers between families of Amphidium Schimper (1856: 39) (Dicranaceae Schimper (1856: 11) to Amphidiaceae Stech (2008: 14), Campylopus Bridel (1819: 71) (Dicranaceae to Leucobryaceae Schimper (1856: 19), Kiaeria I.Hagen (1915: 109) (Dicranaceae to Rhabdoweisiaceae Limpricht (1886: 271), Distichium Bruch \& Schimper (1846: 153) (Ditrichaceae Limpricht (1887: 482) to Distichiaceae Schimper (1860: 135)), Holodontium strictum (Hooker f. \& Wilson 1844: 540) Ochyra (1993: 84) and Hymenoloma Dusén (1905: 19) (Seligeriaceae Schimper (1856: 22) to Hymenolomataceae Ignatov \& Fedosov (2016: 128)), Leptobryum (Bruch \& Schimper) Wilson (1855: 219) (Bryaceae Schwägr. (1830: 47) to Meesiaceae Schimper (1856: 82)), Pohlia Hedwig (1801: 171) and Schizymenium Harvey (1838: 384) (Bryaceae to Mniaceae Schwägrichen (1830: 25)), Sanionia (Amblystegiaceae G.Roth (1899: 6) to Scorpidiaceae Ignatov \& Ignatova (2004: 942)), Warnstorfia Loeske (1907: 310) (Amblystegiaceae to Calliergonaceae Vanderpoorten, Hedenäs, C.J.Cox \& A.J.Shaw (2002: 120)) as well as Isopterygiopsis Z.Iwatsuki (1970: 379) and Platydictya Berkeley (1863: 145) (Hypnaceae to Plagiotheciaceae M.Fleischer (1912: 748)) (Frey \& Stech 2009 and references therein, Fedosov et al. 2016a, 2016b, 2020). Nine of these families represent new families for Antarctica. Except for Mniaceae, they all belong to the two largest moss lineages, the Dicranidae (Amphidiaceae, Distichiaceae, Hymenolomataceae, Leucobryaceae, Rhabdoweisiaceae) or the Hypnales (Calliergonaceae, Pylaisiaceae, Scorpidiaceae), respectively, and were resurrected or newly described based on molecular phylogenetic inferences. The polyphyly of Ditrichum and the Ditrichaceae (Fedosov et al. 2016a) may lead to further taxonomic changes involving the Antarctic species, however, the taxonomic diversity of Antarctic mosses at family level is already much more accurate due to the insights from molecular data.

So far, molecular studies of Antarctic bryophyte species have focused exclusively on mosses. Molecular data (fingerprinting data and/or DNA sequences) have been published for 31 (36\%) of the 116 Antarctic moss species (Fig. 1). The cosmopolitan species Bryum argenteum and Ceratodon purpureus were studied most frequently, followed by the bipolar species Bryum pseudotriquetrum (Hedwig 1801: 190) G.Gaertner, B.Meyer \& Scherbius (1802: 102). The majority of species have, however, only been included in a single study (Fig. 1).

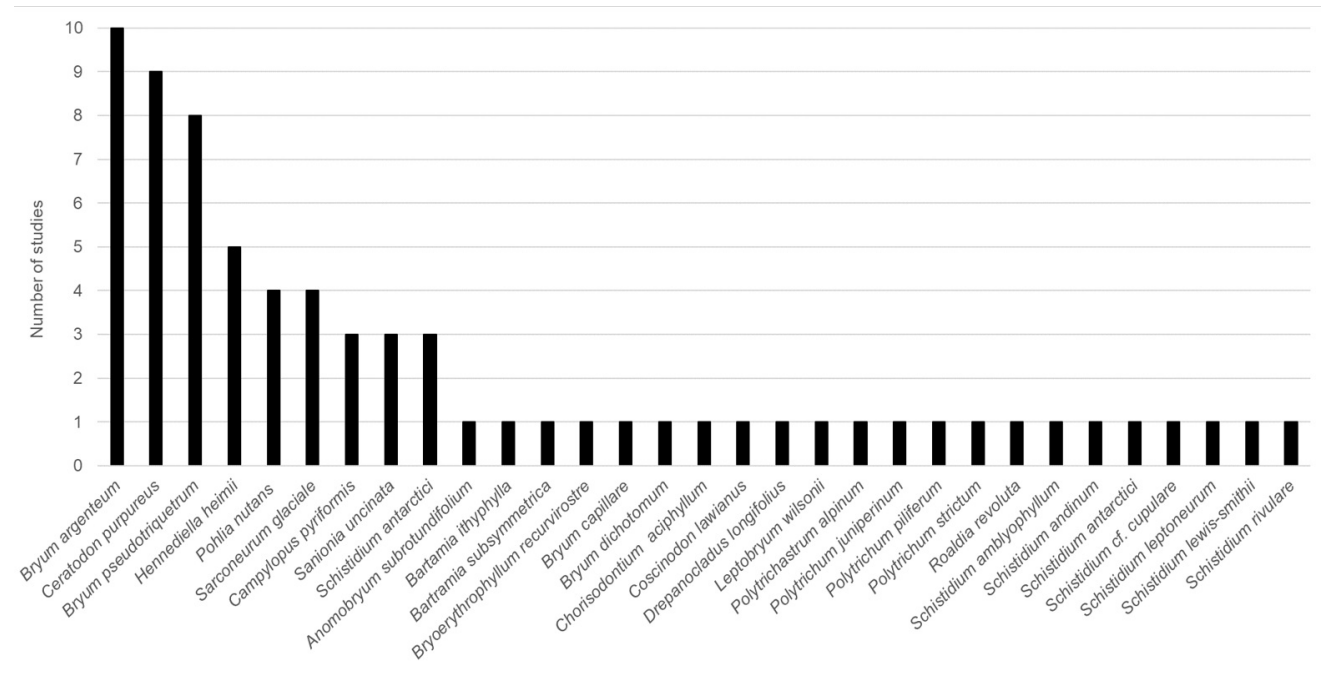

FIGURE 1. Antarctic moss species for which molecular data (fingerprinting and/or DNA sequence data) are available, and numbers of studies addressing these species.

With the advances in sequencing technology, the first studies using Next Generation Sequencing (NGS) for Whole Genome Sequencing (WGS) of organellar genomes of Antarctic bryophyte species (Freitas et al. 2018; Park et al. 2018; Byun et al. 2019; Kim et al. 2019) were published. Currently, the use of NGS for eDNA metabarcoding of environmental samples (soil, air) is starting up as well. Recent studies on algae (Câmara et al. 2021) and fungi (Rosa et al. 2020) detected yet unknown diversity in the soil at a protected and a human-impacted site on Deception Island, South Shetland Islands, and demonstrated that important differences exist between both sites in terms of diversity, 
richness, and abundance of algal and fungal taxa. The detection of DNA of non-native taxa highlighted concerns about human impacts, primarily through tourism and research operations, on future biological colonization processes in Antarctica. Ongoing studies of air and soil samples are expected to provide a better understanding of dispersal and colonization processes of bryophytes in Antarctica as well (own unpublished data), which may be facilitated by an increase in ice-free areas due to climate change.

\section{Conservation of Antarctic bryophyte diversity}

There are currently 71 Antarctic Specially Protected Areas (ASPAs), of which the terrestrial ones vary in size between 0.03 and $91.76 \mathrm{~km}^{2}$, and seven mostly (much) larger Antarctic Specially Managed Areas (ASMAs) with ca 30,246 $\mathrm{km}^{2}$. Of these, 18 mention mosses or liverworts in the summary description in the Antarctic Protected Areas Database (https://www.ats.aq/devph/en/apa-database). Furthermore, areas destined to protect other values may also end up protecting the bryophyte flora, and the ASPA management plans provided in the database may give more details on bryophytes worth of protection. For example, ASPA 140, in Deception Island (South Shetland Islands), is divided into 11 subsites, most of them created to protect some unique aspect of the local island flora. Although bryophytes are not mentioned in the summary, subsite E (Stonethrow ridge), for example, is designated to protect "several very rare mosses, liverworts and lichens" according to its management plan. Currently, 15 Antarctic Conservation Biogeographic Regions (ACBRs), originally proposed in 2012 and representing biologically distinct ice-free areas (a $16^{\text {th }}$ ACBR was proposed by Terauds \& Lee 2016), are used as an important tool in Antarctic science, conservation, management and policy, e.g. in proposing new ASPAs (Terauds \& Lee 2016).

However, Coetzee et al. (2017) pointed out that the network of terrestrial protected areas of Antarctica should be expanded since the ASPAs are generally small, unrepresentative of the continent's biodiversity, and subject to a range of pressures, including local human (research) activities (Hughes et al. 2013). Yet little is known about how effective the ASPAs or ASMAs actually are in protecting the local bryophyte flora, since generally few studies have focused on monitoring of bryophyte populations and comparison of species composition through time in Antarctica (e.g. Wasley et al. 2012; King 2017; Robinson et al. 2018; Câmara et al. 2020). These studies demonstrated that changes in the composition of local moss floras occur and could be linked with environmental changes, in particular climatic changes. Observations such as an increase in populations size of cosmopolitan species (Bryum pseudotriquetrum and Ceratodon purpureus) at the expense of the Antarctic endemic Schistidium (King 2017; Robinson et al. 2018) and disappearance of species from local communities (Câmara et al. 2020) not only indicate the importance of monitoring populations over long periods of time, but may also indicate the need of threat assessment of Antarctic bryophyte species. So far there is no Red List of threatened plant species in Antarctica, and the flora has been generally considered to be at low threat. This, however, may not be true for all species, especially not for the rare or very rare species, which together comprise $40 \%$ of the Antarctic moss flora (Ochyra et al. 2008) and 67\% of the Antarctic liverwort flora (BednarekOchyra et al. 2000).

Knowledge on the distribution and population sizes of species is obviously important to make accurate threat assessments, which will mainly rely on the existing floras (Bednarek-Ochyra et al. 2000; Ochyra et al. 2008), complemented by new data. For example, recent fieldwork and morphological identification allowed the expansion of geographical ranges of several Antarctic bryophyte species (Henriques et al. 2018; Câmara et al. 2017; Suarez et al. 2019). Furthermore, intraspecific molecular analyses allow scientists to incorporate genetic diversity in conservation planning and threat assessment. While DNA sequence variation was found to be low in some Antarctic moss species, e.g. the bank-forming Chorisodontium aciphyllum (Hooker f. \& Wilson 1844: 541) Brotherus (1924: 205) (Biersma et al. 2018b), other species like Bryum argenteum, Ceratodon purpureus, Polytrichum juniperinum and Schistidium antarctici show a considerable genetic diversity in Antarctica, including Antarctic exclusive haplotypes (Pisa et al. 2014; Zaccara et al. 2020; Biersma et al., 2017, 2018a, 2020). The use of both traditional and molecular approaches is therefore useful to assess biodiversity and provide data for decision making processes on conservation.

\section{Future challenges}

Antarctic ecosystems face increasing threats due to global environmental change, despite their remoteness and formal protection status (Bergstrom et al. 2021). Invasive species are a matter of concern as they pose big threats to the native 
local flora, as are pollution, tourism as well as current (fishery) and possible future economic exploitation (e.g. Chown et al. 2012). The latter should not be underestimated, since the region holds about $70 \%$ of the world's freshwater resources as well as yet untouched fossil energy (oil, gas, coal) and mineral (e.g., chromium, copper, gold, iron ore) resources, and the ban on mineral exploitation by the Antarctic Treaty may be revised in 2048 .

To better understand the importance of bryophytes for the Antarctic terrestrial ecosystem, assess the impact of the diverse threats on the Antarctic bryophyte diversity and vegetation, and further develop conservation measures, several research strategies and knowledge gaps should be addressed.

Like in the Arctic (Lewis et al. 2017a), access to collections is still a challenge for Antarctic research. There are few institutions that house significant plant collections from Antarctica, including herbaria BM, BR, PC, NY and US for historical collections and AAS, HO, KRAM and UB for more recent ones, not all are (fully) digitalized and available online. For example, of 6206 occurrences of Antarctic mosses on GBIF (www.gbif.org; search parameters: administrative areas: Antarctica, scientific name: Bryophyta, occurrence status: present, basis of record: preserved specimen; accessed 15-10-2020), 5291 (85\%) were retrieved from herbaria AAS (British Antarctic Survey Antarctic Plant Database), HO and UB.

There may also be (sometimes rare) collections from more remote and inaccessible areas, usually obtained for ecological or chemical studies, that are not properly deposited in a regular collection, making it difficult to access them for systematic research. It is of paramount importance that Antarctic collections are properly deposited and curated in herbaria, and made available to everyone online. As already pointed out by Lewis et al. (2017a), existing collections remain an important considering the high logistics costs associated with polar expeditions to collect new material. Online specimen information for GIS-based research and physical specimens for taxonomic and molecular research, (in particular, NGS approaches that enable the generation of short sequences from old plant material), would foster Antarctic bryology (and polar bryology in general) considerably.

The high costs and complexity of Antarctic logistics, and also the need to comply with the Madrid Protocol for Environmental Protection, and to keep up the Antarctic Treaty spirit of collaboration among parties, make the international collaboration of countries and the bryological community very important, both in sharing logistics and in science. Some countries like Brazil require that a proposal demonstrates the interactions with other research groups within the Treaty parties in order to secure funds. Unfortunately, nowadays there are very few bryologists actively working on Antarctic bryophytes, especially in systematics and taxonomy. There are, however, a considerable number of scientists using Antarctic mosses in studies of ecology, biochemistry, plant physiology, and other scientific areas, which are not the focus of this review.

In terms of species delimitation, relationships and genetic diversity, one obvious knowledge gap is that only about one third of the Antarctic moss species and none of the liverwort species have so far been studied based on molecular data. Furthermore, the studied moss species are unevenly distributed taxonomically. Data on relatively species-rich and taxonomically complex families like Brachytheciaceae, Ditrichaceae, and especially Pottiaceae are still rare, but also Bryaceae are still represented by only few species in the molecular studies. Pottiaceae and Bryaceae in particular contain species of which Antarctic material is difficult to identify based on (gametophytic) morphological characters (Ochyra et al. 2008). Given the results of the recent genus-level studies discussed above (Biersma et al. 2018a, Câmara et al. 2019a), molecular analyses of extended taxon samplings of other genera will likely result in further taxonomic changes and a more accurate assessment of the bryophyte species diversity in Antarctica. One limiting factor, however, may be the availability of collections from rare or very small species that are suitable for DNA sequencing, such as the bipolar Platydictya jungermannioides (Bridel 1812: 255) H.A.Crum (1964: 60), the smallest moss species in Antarctica (Ochyra et al. 2008), and several liverwort species (Bednarek-Ochyra et al. 2000).

To better understand the geographic and evolutionary origins, and patterns of diversification, of the Antarctic bryophyte flora, further taxa from all main phytogeographic elements (Antarctic endemic, sub-Antarctic, southtemperate, bipolar, and cosmopolitan; Ochyra et al. 2008) should be studied by phylogenetic and phylogeographic analyses with appropriate global sampling. At the same time, further analyses of intraspecific genetic variation are needed to understand (i) the role of gene flow (by dispersal to and within Antarctica) in shaping genetic structure, and the roles of historical demography (i.e., survival in refugia) versus local adaptation (as a result of ongoing selective pressure by ecological conditions) in shaping extant diversity (Kennicutt et al. 2014, Lewis et al. 2017a, Zaccara et al. 2020). These questions are particularly important in the light of the contemporary global climate change. Antarctic species may benefit from modest warming and newly available, ice-free terrestrial areas, however, potentially at the expense of loss of genetic diversity and competition by non-native species (Siegert et al. 2019). Specimen-based analyses are necessary to infer the present genetic diversity of Antarctic bryophyte species, as a baseline to monitor future changes. Such data should be complemented by eDNA metabarcoding to infer which diaspores arrive in 
Antarctica by air currents and are deposited in the soil diaspore bank, and may colonize Antarctic terrestrial ecosystems under climate change.

\section{Final remarks}

By force of the Treaty, the whole Antarctic region became dedicated to science 60 years ago, and more professional botanists became involved in Antarctic research than ever before. The first peak of bryological research, characterized by taxonomic studies of newly available collections, culminated in the publication of Antarctic moss and liverwort floras. The local bryophyte flora is now well documented as a basis for ongoing and future research. Improved research facilities in Antarctica, national research programs, international collaborations, and the use of molecular tools like Sanger sequencing and eDNA metabarcoding, offer opportunities for systematic, evolutionary, ecological and biochemical studies. These will bring new insights, perspectives and, surely enough, raise new questions concerning Antarctic bryophyte diversity. Bryology in Antarctica is still far from being well understood, and progress may be challenged due to few scientists currently being dedicated to Antarctic bryophytes. However, considering the accelerating environmental changes and the geopolitical importance of science in Antarctica, together with the opportunities described above, Antarctic bryological research may reach another peak in the near future.

\section{Acknowledgements}

For the Antarctic research, we thank the Brazilian funding agency CNPq, Ministry of Science and Technology (MCTI), Brazilian Antarctic Program (PROANTAR) and Brazilian Navy, grant number 64/2013. We thank all bryologists involved in collecting specimens during PROANTAR fieldworks in Antarctica, especially Juçara Bordin, Diego Henriques, Denilson Peralta, Daiane Valente, Tamara Dantas, Eduardo Amorim, Guillermo Suárez, Julia Mundin, Barbara Guedes and Hermeson Oliveira. Extra funds were made available by Congresswoman Jô Moraes and the Institute for Biological Sciences at University of Brasília. For Arctic research (contributing specimens to the Brazil-funded bipolar bryophyte project), M.S. and colleague Hans Kruijer received support from the Netherlands Organisation for Scientific Research (NWO grant ALW-NAP/08-01), EU programs INTERACT Transnational Access and ARCFAC V (grants ARCFAC-026129-2008-31 and ARCFAC-026129-2009-123), Royal Netherlands Navy (Jan Mayen expedition 2014), and NWO-funded Netherlands Scientific Expedition Edgeøya Spitsbergen (SEES) 2015.

\section{References}

Adam, K.D., Selkirk, P.M., Connett, M.B. \& Walsh, S.M. (1997) Genetic variation in populations of the moss Bryum argenteum in East Antarctica. In: Battaglia, B., Valencia, J. \& Walton, D.W.H. (Eds.) Antarctic Communities. Species, Structure and Survival. Cambridge University Press, Cambridge, pp. 33-38.

Ando, H. (1979) Ecology of terrestrial plants in the Antarctic with particular reference to bryophytes. Memoirs of National Institute of Polar Research Special Issue 11: 81-103.

Bartling, F.G. (1831) Colobanthus. In: Presl, K.B. Reliquiae Haenkeanae; Descriptiones et Icones Plantarum, Quas in America Meridionali et Boreali, in Insulis Philippinis et Marianis Collegit Thaddaeus Haenke, Vol. 2, Fasc. 1. J.G. Calve, Pragae, 56 pp.

Bednarek-Ochyra, H., Váňa, J., Ochyra, R. \& Smith, R.I.L. (2000) The Liverwort Flora of Antarctica. Polish Academy of Sciences, Krakow, 236 pp.

Bergstrom, D.M., Wienecke, B.C., van den Hoff, J., Hughes, L., Lindenmayer, D.B., Ainsworth, T.D., Baker, C.M., Bland, L., Bowman, D.M.J.S., Brooks, S.T., Canadell, J.G., Constable, A.J., Dafforn, K.A., Depledge, M.H., Dickson, C.R., Duke, N.C., Helmstedt, K.J., Holz, A., Johnson, C.R., McGeoch, M.A., Melbourne-Thomas, J., Morgain, R., Nicholson, E., Prober, S.M., Raymond, B., Ritchie, E.G., Robinson, S.A., Ruthrof, K.X., Setterfield, S.A., Sgrò, C.M., Stark, J.S., Travers, T., Trebilco, R., Ward, D.F.L., Wardle, G.M., Williams, K.J., Zylstra, P.J. \& Shaw, J.D. (2021) Combating ecosystem collapse from the tropics to the Antarctic. Global Change Biology 27: 1692-1703.

https://doi.org/10.1111/gcb.15539

Berkeley, M.J. (1863) Handbook of Brish Mosses, comprising all that are known to be natives of the British Isles. Lovell Revee \& Co., 
London, $324 \mathrm{pp}$.

https://doi.org/10.5962/bhl.title.55400

Bescherelle, E. (1885) Mousses Nouvelles de L'Amérique Australe. Bulletin de la Société Botanique de France 32: LXIII-LXVIII. https://doi.org/10.1080/00378941.1885.10830136

Biersma, E.M., Convey, P., Wyber, R., Robinson, S.A., Dowton, M., van de Vijver, B., Linse, K., Griffiths, H. \& Jackson, J.A. (2020) Latitudinal Biogeographic Structuring in the Globally Distributed Moss Ceratodon purpureus. Frontiers in Plant Science 11: 502359 .

https://doi.org/10.3389/fpls.2020.502359

Biersma, E.M., Jackson, J.A., Bracegirdle, T.J., Griffiths, H., Linse, K. \& Convey, P. (2018b) Low genetic variation between South American and Antarctic populations of the bank-forming moss Chorisodontium aciphyllum (Dicranaceae). Polar Biology 41: 599610. https://doi.org/10.1007/s00300-017-2221-1

Biersma, E.M., Jackson, J.A., Hyvönen, J., Linse, K., Griffiths, H. \& Convey, P. (2017) Global biogeographic patterns in bipolar moss species. Royal Society Open Science 4: 170147.

https://doi.org/10.1098/rsos.170147

Biersma, E.M., Jackson, J.A., Stech, M., Griffiths, H., Linse, K. \& Convey, P. (2018a) Molecular data suggest long-term in situ Antarctic persistence within Antarctica's most speciose plant genus, Schistidium. Frontiers in Ecology and Evolution 6: 77. https://doi.org/10.3389/fevo.2018.00077

Bridel, S.E. (1801) Animadversiones in Muscologiae Recentiorum Tomum secundum, ab ipso auctore propositae. Journal für die Botanik (Schrader) 1800 (1): 268-299.

Bridel, S.E. (1812) Muscologiae Recentiorum Supplementum seu Species Muscorum 2: 1-257.

Bridel, S.E. (1819) Muscologiae Recentiorum Supplementum 4: 1-220.

Bridel, S.E. (1826) Bryologia Universa seu systematica ad novam methodum disposition, vol. 1. historia et description omnium muscorum frondosorum huscusque cognitorum cum synonymia ex auctoribus probatissimis. Lipsiae (Leipzig), $856 \mathrm{pp}$.

Brotherus, V.F. (1925) Musci (Laubmoose) 2. In: Engler, A. (Ed.) Die natürlichen Pflanzenfamilien, nebst ihren Gattungen und wichtigeren Arten, insbesondere den Nutzpflanzen, unter Mitwirkung zahlreicher hervorragender Fachgelehrten, Zweite Auflage, Bd. 11. Wilhelm Engelmann, Leipzig, 542 pp.

Bruch, P., Schimper, W.P. \& Gümbel, T. (1845) Distichium. Bryologia Europaea seu genera Muscorum Europaeorum monographice illustrata: Fasciculus XXIX-XXX, 1-200.

Bruch, P., Schimper, W.P. \& Gümbel, T. (1845) Schistidium. Bryologia Europaea seu genera Muscorum Europaeorum monographice illustrata: Fasciculus XXV-XXVIII, 1-10.

Byun, M.Y., Cho, S.M., Lee, J., Park, H. \& Lee, H. (2019) The complete mitochondrial genome of an Antarctic moss Chorisodontium aciphyllum (Hook. f. \& Wilson) Broth. Mitochondrial DNA Part B 4: 1714-1715.

https://doi.org/10.1080/23802359.2019.1605856

Câmara, P.E.A.S., Carvalho-Silva, M., Henriques, D.K., Guerra, J., Gallego, M.T., Rios Poveda, D. \& Stech, M. (2018) Pylaisiaceae Schimp. (Bryophyta) revisited. Journal of Bryology 40: 251-264.

https://doi.org/10.1080/03736687.2018.1472850

Câmara, P.E.A.S., Silva, B.G.C., Carvalho-Silva, M. \& Henriques, D.K. (2017) The moss flora of Ostrov Geologov (Geologists Island), Maxwell Bay, King George Island, Antarctica. Boletín de la Sociedad Argentina de Botánica 52: 251-255. https://doi.org/10.31055/1851.2372.v52.n2.17439

Câmara, P.E.A.S., Soares, A.E.R., Henriques, D.K., Peralta, D.F., Bordin, J., Carvalho-Silva, M. \& Stech, M. (2019a) New insights into the species diversity of Bartramia Hedw. (Bryophyta) in Antarctica. Antarctic Science 31: 208-215. https://doi.org/10.1017/S0954102019000257

Câmara, P.E.A.S., Valente, D.V. \& Sancho, L.G. (2020) Changes in the moss (Bryophyta) flora in the vicinity of the Spanish Juan Carlos I Station (Livingston island, Antarctica) over three decades. Polar Biology 43: 1745-1752.

https://doi.org/10.1007/s00300-020-02740-0

Câmara, P.E.A.S., Valente, D.V., Amorim, E.T., Henriques, D.K., Carvalho-Silva, M., Convey, P. \& Stech, M. (2019b) Integrated analysis of intraspecific diversity in Roaldia revoluta (Mitt.) P.E.A.S. Câmara \& M. Carvalho-Silva (Bryophyta) in Antarctica. Polar Biology 42: 485-496. https://doi.org/10.1007/s00300-018-2437-8

Câmara, P.E.A.S. \& Carvalho-Silva, M. (2020) 180 years of Botanical Investigations in Antarctica and the Role of Brazil. Acta Botanica Brasilica 34. [Online access] https://doi.org/10.1590/0102-33062020abb0172

Câmara, P.E.A.S., Carvalho-Silva, M., Pinto, O.H.B., Amorim, E.T., Henriques, D.K., Silva, T.H., Pellizzari, T., Convey, P. \& Losa, L.H. 
(2021) Diversity and Ecology of Chlorophyta (Viridiplantae) Assemblages in Protected and Non-protected Sites in Deception Island (Antarctica, South Shetland Islands) Assessed Using an NGS Approach. Microbial Ecology 81: 323-334.

https://doi.org/10.1007/s00248-020-01584-9

Cardot, J. (1906) Notice Préliminaire sur les Mousses Recueillies par l'Expédition Antartique Suédoise. Bulletin de l'Herbier Boissier, sér. 2, 6: 1-88.

Chown, S.L., Lee, J.E., Hughes, K.A., Barnes, J., Barrett, P.J., Bergstrom, D.M., Convey, P., Cowan, D.A., Crosbie, K., Dyer, G., Frenot, Y., Grant, S.M., Herr, D., Kennicutt II, M.C., Lamers, M., Murray, A., Possingham, H.P., Reid, K., Riddle, M.J., Ryan, P.G., Sanson, L., Shaw, J.D., Sparrow, M.D., Summerhayes, C., Terauds, A. \& Wall, D.H. (2012) Challenges to the Future Conservation of the Antarctic. Science 337 (6091): 158-159. https://doi.org/10.1126/science.1222821

Clarke, L.J., Ayre, D.J. \& Robinson, S.A. (2008) Somatic mutation and the Antarctic ozone hole. Journal of Ecology 96: $378-385$. https://doi.org/10.1111/j.1365-2745.2007.01347.x

Clarke, L.J., Robinson, S.A. \& Ayre, D.J. (2009) Genetic structure of Antarctic populations of the moss Ceratodon purpureus. Antarctic Science 21: 51-58. https://doi.org/10.1017/S0954102008001466

Coetzee, B.W.T., Convey, P. \& Chown, S.L. (2017) Expanding the Protected Area Network in Antarctica is Urgent and Readily Achievable. Conservation Letters 10 (6): 670-680.

https://doi.org/10.1111/conl.12342

Crum, H. (1964) Mosses of the Douglas Lake region of Michigan. The Michigan Botanist 3 (2): 1-63.

Dale, T.M., Skotnicki, M.L., Adam, K.D. \& Selkirk, P.M. (1999) Genetic diversity in the moss Hennediella heimii in Miers Valley, southern Victoria Land, Antarctica. Polar Biology 21: 228-233. https://doi.org/10.1007/s003000050357

Desvaux, E.-E. (1853) Flora Chilena, 6. Historia Fisica y Politica de Chile, Botanica, 551 pp.

Dusén, P.K.H. (1905) Beiträge zur Bryologie der Magellansländer, von Westpatagonien und Südchile. Arkiv för Botanik 4 (1): 1-46.

Ellis, L.T., Asthana, A.K., Gupta, R., Nath, V., Sahu, V., Bednarek-Ochyra, H., Ochyra, R., Cykowska, B., Calvo Aranda, S., Fischer, E., Gabriel, R., Górski, P., Gremmen, N., Hespanhol, H., Kurbatova, L.E., Smith, R.I.L., Long, D.G., Bell, D., Mogro, F., Sérgio, C., Garcia, C.A., Stow, S., Martins, A., Smith, V.R., Váňa, J. \& Vanderpoorten, A. (2013a) New national and regional bryophyte records, 34. Journal of Bryology 35: 62-70. https://doi.org/10.1179/1743282012Y.0000000042

Ellis, L.T., Bednarek-Ochyra, H., Ochyra, R., Benjumea, M.J., Saïs, L.V., Caparrós, R., Lara, F., Mazimpaka, V., Dulin, M.V., Gailleti, R., Gremmen, N., Grundling, P.L., Heras, P., Infante, M., Huttunen, S., Ignatov, M.S., Korvenpää, T., Lebouvier, M., Lewis Smith, R.I., Lin, S.-H., Yang, J.-D., Linström, A., Plášek, V., Rosselló, J.A., Sawicki, J., van Rooy, J., Smith, V.R. (2013b) New national and regional bryophyte records, 35. Journal of Bryology 35: 129-139.

https://doi.org/10.1179/1743282013Y.0000000049

Fedosov, V.E., Fedorova, A.V., Larraín, J., Bonfim Santos, M., Stech, M., Kučera, J., Brinda, J.C., Tubanova, D.Y., Von Konrat, M., Ignatova, E.A. \& Ignatov, M.S. (2020) Unity in diversity: Phylogeny of Rhabdoweisiaceae (Dicranales, Bryophyta). Botanical Journal of the Linnean Society 195: 545-567.

https://doi.org/10.1093/botlinnean/boaa087

Fedosov, V.E., Fedorova, A.V., Fedosov, A.E. \& Ignatov, M.S. (2016a) Phylogenetic inference and peristome evolution in haplolepideous mosses, focusing on Pseudoditrichaceae and Ditrichaceae s.1. Botanical Journal of the Linnean Society 181: 139-155. https://doi.org/10.1111/boj.12408

Fedosov, V.E., Fedorova, A.V., Troitsky, A.V., Bobrova, V.K. \& Ignatov, M.S. (2016b) On the systematic position of Hymenoloma. Arctoa 25: $119-130$

https://doi.org/10.15298/arctoa.25.10

Fleischer, M. (1912) Laubmoose. Nova Guinea: Resultats de L'expédition Scientifique Neerlandaise a la Nouvelle-Guinee en 1907 et 19098 (2): 735-753.

Freitas, K.E.J., Metz, G.F., Cañon, E.R.P., Roesch, L.F.W., Pereira, A.B. \& Victoria, F.C. (2018) Characterization and Phylogenetic Analysis of Chloroplast and Mitochondria Genomes from the Antarctic Polytrichaceae Species Polytrichum juniperinum and Polytrichum strictum. Diversity 10 (3): 89.

https://doi.org/10.3390/d10030089

Frey, W. \& Stech, M. (2009) Marchantiophyta, Bryophyta, Anthocerotophyta. In: Frey, W. (Ed.) Syllabus of Plant Families. A. Engler's Syllabus der Pflanzenfamilien, 13th ed., Part 3 Bryophytes and seedless Vascular Plants. Borntraeger, Stuttgart, pp. 13-263.

Gaertner, G., Meyer, B. \& Scherbius, J. (1802) Oekonomisch-Technische Flora der Wetterau. Vol. 3. Frankfurt am Main, 388 pp. Greene, S.W. (1964) Problems and progress in Antarctic bryology. In: Carrick, R., Holdgate, M.W. \& Prévost, J. (Eds.) Biologie antarctique. 
Proceedings of the First Symposium on Antarctic Biology, Paris, 2-8 Sept. 1962. Hermann, Paris, pp. 173-179.

Greene, S.W. (1967) The changing pattem of Antarctic botanical studies. Japanese Antarctic Research Expedition Scientific Reports,

Special Issue. I. Proceedings of the Symposium on Pacific-Antarctic Sciences. National Science Musecum, Department of Polar

Research, Tokyo, pp. 236-244.

Hagen, I.S. (1915) Forarbejder til en Norsk Løvmosflora XX. Dicranaceae. Kongelige Norske Videnskabers Selskabs Skrifter: 1-192.

Harvey, W.H. (1838) The Genera of South African Plants. Arranged according to the Natural System, Cape Town, 483 pp.

Hebel, I., Dacasa Rüdinger, M.C., Jaña, R.A. \& Bastias, J. (2018) Genetic Structure and Gene Flow of Moss Sanionia uncinata (Hedw.)

Loeske in Maritime Antarctica and Southern-Patagonia. Frontiers in Ecology and Evolution 6: 152.

https://doi.org/10.3389/fevo.2018.00152

Hedenäs, L. (2012) Global phylogeography in Sanionia uncinata (Amblystegiaceae: Bryophyta). Botanical Journal of the Linnean Society 168: $19-42$.

https://doi.org/10.1111/j.1095-8339.2011.01189.x

Hedwig, J. (1801) Species Muscorum Frondosorum, descriptae et tabulis aeneis LXXVII coloratis illustratae. J.A. Barth, Leipzig, 325

pp.

https://doi.org/10.5962/bhl.title.26

Henriques, D.K., Silva, B.G., Zuñiga, G.E. \& Câmara, P.E.A.S. (2018) Contributions to the bryological knowledge of ASPA 125, Fildes Peninsula, King George Island. Biological Research 51: 29.

https://doi.org/10.1186/s40659-018-0178-3

Hills, S.F.K., Stevens, M.I. \& Gemmill, C.E.C. (2010) Molecular support for Pleistocene persistence of the continental Antarctic moss Bryum argenteum. Antarctic Science 22: 721-726.

https://doi.org/10.1017/S0954102010000453

Hooker, J.D. \& Wilson, W. (1844) Musci Antarctici; being Characters with brief descriptions of the new species of Mosses discovered during the voyage of H.M. Discovery Ships, Erebus and Terror, in the Southern Circumpolar Regions, together with those of Tasmania and New Zealand. London Journal of Botany 3: 533-556.

Hughes, K.A., Pertierra, L.R. \& Walton, D.W.H. (2013) Area protection in Antarctica: How can conservation and scientific research goals be managed compatibly? Environmental Science \& Policy 31: 120-132.

https://doi.org/10.1016/j.envsci.2013.03.012

Ignatov, M.S. \& Ignatova, E.A. (2004) Flora mkhov srednei chasti evropeiskoi Rossii. Tom 2. Fontinalaceae-Amblystegiaceae. Moss flora of the Middle European Russia. Volume 2: Fontinalaceae-Amblystegiaceae. Arctoa 11(Supplement 2): 609-960.

Ignatov, M.S. \& Fedosov, V.E. (2016) On the systematic position of Hymenoloma (Bryophyta). Arctoa 25 (1): 119-130. https://doi.org/10.15298/arctoa.25.10

Iwatsuki, Z. (1970) A revision of Plagiothecium and its related genera in Japan and her adjacent areas. Journal of the Hattori Botanical Laboratory 33: 331-380.

Burton-Johnson, A., Black, M., Fretwell, P.T. \& Kaluza-Gilbert, J. (2016) An automated methodology for differentiating rock from snow, clouds and sea in Antarctica from Landsat 8 imagery: a new rock outcrop map and area estimation for the entire Antarctic continent.

The Cryosphere 10: 1665-1677.

https://doi.org/10.5194/tc-10-1665-2016

Kato, K., Arikawa, T., Imura, S. \& Kanda, H. (2013) Molecular identification and phylogeny of an aquatic moss species in Antarctic lakes. Polar Biology 36: 1557-1568. https://doi.org/10.1007/s00300-013-1373-x

Kennicutt, M.C., Chown, S.L., Cassano, J.J., Liggett, D., Massom, R., Peck, L.S., Rintoul, S.R., Storey, J.W.V., Vaughan, D.G., Wilson, T.J. \& Sutherland, W.J. (2014) Six priorities for Antarctic science. Nature 512: 23-25.

Khan, N., Tuffin, M., Stafford, W., Cary, C., Lacap, D.C., Pointing, S.B. \& Cowan, D. (2011) Hypolithic microbial communities of quartz rocks from Miers Valley, McMurdo Dry Valleys, Antarctica. Polar Biology 34: 1657-1668. https://doi.org/10.1007/s00300-011-1061-7

Kim, S.C., Byun, M.Y., Kim, J.H. \& Lee, H. (2019) The complete chloroplast genome of an Antarctic moss Syntrichia filaris (Müll.Hal.) R.H. Zander. Mitochondrial DNA Part B 4: 2303-2304.

https://doi.org/10.1080/23802359.2019.1627945

King, D.H. (2017) Monitoring Antarctic bryophyte communities in a time of change. PhD Thesis, University of Wollongong, Australia.

Kunth, K.S. (1823) in Humboldt, F.W.H.A, Bonpland, A.J.A, Kunth, K.S. Nova Genera et Species Plantarum 6: 1-19.

Kurbatova, L.E. \& Ochyra, R. (2012) Two Noteworthy Additions to the Moss Flora of the Schirmacher Oasis in Continental Antarctica. Cryptogamie, Bryologie 33: 159-167.

https://doi.org/10.7872/cryb.v33.iss2.2012.159

Lewis, L.R., Biersma, E.M., Carey, S.B., Holsinger, K., McDaniel, S.F., Rozzi, R. \& Goffinet, B. (2017b) Resolving the northern 
hemisphere source region for the long distance dispersal event that gave rise to the South American endemic dung moss Tetraplodon fuegianus. American Journal of Botany 104: 1651-1659.

https://doi.org/10.3732/ajb.1700144

Lewis, L.R., Ickert-Bond, S.M., Biersma, E.M., Convey, P., Goffinet, B., Hassel, K., Kruijer, J.D., La Farge, C., Metzgar, J., Stech, M., Villarreal, J.C. \& McDaniel, S.F. (2017a) Future directions and priorities for Arctic bryophyte research. Arctic Science 3: $475-497$. https://doi.org/10.1139/as-2016-0043

Li, S.-P., Ochyra, R., Wu, P.-C., Seppelt, R.D., Cai, M.-H., Wang, H.-Y. \& Li, C.-S. (2009) Drepanocladus longifolius (Amblystegiaceae), an addition to the moss flora of King George Island, South Shetland Islands, with a review of Antarctic benthic mosses. Polar Biology 32: 1415-1425.

https://doi.org/10.1007/s00300-009-0636-z

Limpricht, K.G. (1885-1889) Die Laubmoose Deutschlands, Oesterreichs und der Schweiz 1. Eduard Kummer, Leipzig, 836 pp.

Lindberg, S.O. (1866) Förteckning öfver mossor insamlade under de Svenska expeditionerna till Spitsbergen 1858 och 1861 . Öfversigt af Kongl. Vetenskaps-Akademiens Förhandlingar 23 (10): 535-561.

Liu, S., Zhang, Z., Wang, N., Cong, B., Zhang, P., Lin, X. \& Huang, X. (2014) Phylogenetic analysis and in vitro culture of mosses from the Antarctic Fildes Peninsula. Advances in Polar Science 25: 97-104.

Loeske, L. (1907) Drepanocladus, eine biologische Mischgattung. Hedwigia 46 (5): 300-321.

Melick, D.R., Tarnawski, M.G., Adam, K.D. \& Seppelt, R.D. (1994) Isozyme variation in three mosses from the Windmill Islands oasis, Antarctica: a preliminary study. Biodiversity Letters 2: 21-27.

https://doi.org/10.2307/2999697

Mitten, W. (1859) Musci indiae Orientalis, an Enumeration of the Mosses of the West Indies. Journal of the Proceedings of the Linnean Society, Botany, Supplement 2: 1-171. https://doi.org/10.5962/bhl.title.156377

Ochyra, R. (1993) Antipodal mosses: I. A revision of the genus Holodontium (Musci, Seligeriaceae). Fragmenta Floristica et Geobotanica 38: $1-757$.

Ochyra, R., Smith, R.I.L. \& Bednarek-Ochyra, H. (2008) The Illustrated Moss Flora of Antarctica. Cambridge: Cambridge University Press, $685 \mathrm{pp}$.

Park., M., Park, H., Lee, H., Lee, B.-H. \& Lee, J. (2018) The Complete Plastome Sequence of an Antarctic Bryophyte Sanionia uncinata (Hedw.) Loeske. International Journal of Molecular Sciences 19: 709. https://doi.org/10.3390/ijms19030709

Piñeiro, R., Popp, M., Hassel, K., Listl, D., Westergaard, K.B., Flatberg, K.I., Stenøien, H.K. \& Brochmann, C. (2012) Circumarctic dispersal and long-distance colonization of South America: the moss genus Cinclidium. Journal of Biogeography 39: $2041-2051$. https://doi.org/10.1111/j.1365-2699.2012.02765.x

Pisa, S., Biersma, E. M., Convey, P., Patiño, J., Vanderpoorten, A., Werner, O. \& Ros, R.M. (2014) The cosmopolitan moss Bryum argenteum in Antarctica: recent colonisation or in situ survival? Polar Biology 37: 1469-1477. https://doi.org/10.1007/s00300-014-1537-3

Rankin, A.H., Pressel, S., Ducket, J., Rimington, W.R., Hawes, I., Sumner, D.Y., Mackey, T.J., Castendyke, D., Schneider, H. \& Jungblut, A.D. (2017) Characterisation of a deep-water moss from the perennially ice-covered Lake Vanda, Antarctica. Polar Biology 40: 2063-2076. https://doi.org/10.1007/s00300-017-2127-y

Robinson, S.A., King, D.H., Bramley-Alves, J., Waterman, M.J., Ashcroft, M.B., Wasley, J., Turnbull, J.D., Miller, R.E., Ryan-Colton, E., Benny, T., Mullany, K., Clarke, L.J., Barry, L.A. \& Hua, Q. (2018) Rapid change in East Antarctic terrestrial vegetation in response to regional drying. Nature Climate Change 8: 879-884.

https://doi.org/10.1038/s41558-018-0280-0

Rosa, L.H., da Silva, T.H., Ogaki, M.B., Pinto, O.H.B., Stech, M., Convey, P., Carvalho-Silva, M., Rosa, C.A. \& Câmara, P.E.A.S. (2020) DNA metabarcoding uncovers fungal diversity in soils of protected and non-protected areas on Deception Island, Antarctica. Scientific Reports 10: 21986.

https://doi.org/10.1038/s41598-020-78934-7

Roth, G. (1899) Übersicht über die Familie der Hypnaceen. Beiblatt zur Hedwigia 38: 3-8.

Saługa, M., Ochyra, R., Żarnowiec, J. \& Ronikier, M. (2018) Do Antarctic populations represent local or widespread phylogenetic and ecological lineages? Complicated fate of bipolar moss concepts with Drepanocladus longifolius as a case study. Organisms Diversity and Evolution 18: 263-278.

https://doi.org/10.1007/s13127-018-0372-8

Savicz-Lubitskaya, L.I. \& Smirnova, Z.N. (1965) De Grimmia antarctici Card. ex Antarctide Orientalis. Novosti Sistematiki Nizshikh Rastenii 2: 251-257. 
https://doi.org/10.31111/nsnr/1965.2.251b

Schimper, W.P. (1856) Corollarium Bryologiae Europaeae: Conspectum Diagnosticum Familiarum, Generum et Specierum, Adnotationes Novas Atque Emendationes Complectens. E. Schweizerbart, Stuttgart, 140 pp.

Schimper, W.P. (1860) Synopsis muscorum Europaeorum praemissa introductione de elementis bryologicis tractante. Stuttgartiae: Schweizerbart.

Schwägrichen, F. (1830) Species muscorum frondosorum. Pars I. In: Willdenow, C.L. (Ed.) Caroli a Linné Species plantarum exhibentes plantas rite cognitas ad genera relatas cum differentiis specificis, nominibus trivialibus, synonymis selectis, locis natalibus secundum systema sexuale digestas. Ed. 4. 5(2[1]). Berolini: Impensis G.C. Nauck.

Selkirk, P.M., Skotnicki, M., Adam, K.D., Connett, M.B., Dale, T., Joe, J.W. \& Armstrong, J. (1997) Genetic variation in Antarctic populations of the moss Sarconeurum glaciale. Polar Biology 18: 344-350.

https://doi.org/10.1007/s003000050198

Selkirk, P.M., Skotnicki, M.L., Ninham, J., Connett, M.B. \& Armstrong, J. (1998) Genetic variation and dispersal of Bryum argenteum and Hennediella heimii populations in the Garwood Vaelly, southern Victoria Land, Antarctica. Antarctic Science 10: 423-430. https://doi.org/10.1017/S0954102098000510

Seppelt, R.D., Lewis Smith, R.I. \& Kanda, H. (1998) Antarctic Bryology: Past Achievements And New Perspectives. Journal of the Hattori Botanical Laboratory 84: 203-239.

Siegert, M., Atkinson, A., Banwell, A., Brandon, M., Convey, P., Davies, B., Downie, R., Edwards, T., Hubbard, B., Marshall, G., Rogelj, J., Rumble, J., Stroeve, J. \& Vaughan, D. (2019) The Antarctic Peninsula Under a $1.5^{\circ} \mathrm{C}$ Global Warming Scenario. Frontiers in Environmental Science 7: 102. https://doi.org/10.3389/fenvs.2019.00102

Skotnicki, M.L., Selkirk, P.M. \& Dale, T.M. (1997) RAPD profiling of genetic variation in Antarctic mosses. In: Lyons, W.B., HowardWilliams, C. \& Hawes, I. (Eds.) Ecosystem Processes in Antarctic Ice-Free Landscapes. Rotterdam: Balkema, pp. $129-136$.

Skotnicki, M.L., Ninham, J.A. \& Selkirk, P.M. (1998a) High levels of RAPD diversity in the moss Bryum argenteum in Australia, New Zealand, and Antarctica. The Bryologist 101: 412-421.

https://doi.org/10.2307/3244180

Skotnicki, M.L., Selkirk, P.M. \& Beard, C. (1998b) RAPD profiling of genetic diversity in two populations of the moss Ceratodon purpureus in Victoria Land, Antarctica. Polar Biology 19: 172-176. https://doi.org/10.1017/S0954102098000510

Skotnicki, M.L., Selkirk, P.M. \& Ninham, J.A.(1998c) RAPD analysis of genetic variation and dispersal of the moss Bryum pseudotriquetrum from Southern Victoria Land, Antarctica. Polar Biology 20: 121-126.

https://doi.org/10.1007/s003000050285

Skotnicki, M.L., Ninham, J.A. \& Selkirk, P.M. (1999a) Genetic diversity and dispersal of the moss Sarconeurum glaciale on Ross Island, East Antarctica. Molecular Ecology 8: 753-762. https://doi.org/10.1046/j.1365-294X.1999.00619.x

Skotnicki, M.L., Selkirk, P.M. \& Ninham, J.A. (1999b) RAPD analysis of genetic variation and dispersal of the moss Bryum argenteum in Ross Island and Victoria Land, Antarctica. Polar Biology 21: 417-422. https://doi.org/10.1007/s003000050382

Skotnicki, M., Ninham, J. \& Selkirk, P.M. (2000) Genetic diversity, mutagenesis and dispersal of Antarctic mosses-a review of progress with molecular studies. Antarctic Science 12: 363-373.

https://doi.org/10.1017/S0954102000000419

Skotnicki, M.L., Selkirk, P.M., Broady, P., Adam, K.D. \& Ninham, J.A. (2001) Dispersal of the moss Campylopus pyriformis on geothermal ground near the summits of Mount Erebus and Mount Melbourne, Victoria Land, Antarctica. Antarctic Science 13: 280-285. https://doi.org/10.1017/S0954102001000396

Skotnicki, M.L., Bargagli, R. \& Ninham, J.A. (2002) Genetic diversity in the moss Pohlia nutans on geothermal ground of Mount Rittman, Victoria Land, Antarctica. Polar Biology 25: 771-777. https://doi.org/10.1007/s00300-002-0418-3

Skotnicki, M.L., Mackenzie, A. \& Selkirk, P.M. (2004a) Mosses surviving on the edge: Origins, genetic diversity, and mutation in Antarctica. In: Goffinet, B., Hollowell, V. \& Magill, R. (Eds.) Molecular systematics of bryophytes, 98. Monographs in Systematic Botany from the Missouri Botanical Garden, pp. 388-403.

Skotnicki, M.L., Mackenzie, A., Ninham, J.A. \& Selkirk, P.M. (2004b) High levels of genetic variability in the moss Ceratodon purpureus from continental Antarctica, subantarctic Heard and Macquarie islands, and Australasia. Polar Biology 27: 687-698. https://doi.org/10.1007/s00300-004-0640-2

Skotnicki, M.L., Mackenzie, A., Clements, M.A. \& Selkirk, P.M. (2005) DNA sequencing and genetic diversity of the 18S-26S nuclear ribosomal internal transcribed spacers (ITS) in nine Antarctic moss species. Antarctic Science 17: 377-384. 
https://doi.org/10.1017/S0954102005002816

Skotnicki, M.L., Selkirk, P.M. \& Boger, S.D. (2012) New records of three moss species (Ptychostomum pseudotriquetrum, Schistidium antarctici, and Coscinodon lawianus) from the southern Prince Charles Mountains, Mac. Robertson Land, Antarctica. Polar Record 48: $394-400$.

https://doi.org/10.1017/S0032247412000186

Smith, G.L. (1971) A conspectus of the genera of Polytrichaceae. Memoirs of the New York Botanical Garden 21: 1-83.

Sollman, P. (2015) The genus Bryoerythrophyllum (Musci, Pottiaceae) in Antarctica. Polish Botanical Journal 50: 19-25. https://doi.org/10.1515/pbj-2015-0004

Stech, M. \& Frey, W. (2008) A morpho-molecular classification of the mosses (Bryophyta). Nova Hedwigia 86: 1-21. https://doi.org/10.1127/0029-5035/2008/0086-0001

Stech, M. \& Quandt, D. (2010) 20,000 species and five key markers: the status of molecular bryophyte phylogenetics. Phytotaxa 9: $196-228$. https://doi.org/10.11646/phytotaxa.9.1.11

Stevens, M.I., Hunger, S.A., Hills, S.F.K. \& Gemill, C.E.C. (2007) Phantom hitch-hikers mislead estimates of genetic variation in Antarctic mosses. Plant Systematics and Evolution 263: 191-201. https://doi.org/10.1007/s00606-006-0484-z

Suárez, G.M., Bordin, J. \& Câmara, P.E.A.S. (2019) Syzygiella teres (Marchantiophyta) in the Elephant Island, Antarctica. Boletín de la Sociedad Argentina de Botánica 54: 185-189. https://doi.org/10.31055/1851.2372.v54.n2.24363

Swartz, O. (1803) Cinclidium eine neue Moos-Gattung, entdeckt und beschrieben von Ol. Swartz. Journal für die Botanik (Schrader) 1801 (1): 25-30.

Terauds, A. \& Lee, J.R. (2016) Antarctic biogeography revisited: updating the Antarctic Conservation Biogeographic Regions. Diversity and Distributions 22: 836-840.

https://doi.org/10.1111/ddi.12453

Vanderporten, A., Hedenäs, L., Cox, C.J. \& Shaw, A.J. (2002) Circumscription, classification, and taxonomy of Amblystegiaceae (Bryopsida) inferred from nuclear and chloroplast DNA sequence data and morphology. Taxon 51 (2): 115-122. https://doi.org/10.2307/1554968

Wasley, J., Robinson, S.A., Turnbull, J.D., King, D.H., Wanek, W. \& Popp, M. (2012) Bryophyte species composition over moisture gradients in the Windmill Islands, East Antarctica: development of a baseline for monitoring climate change impacts. Biodiversity 13: $257-264$. https://doi.org/10.1080/14888386.2012.712636

Wilson, W. (1855) Bryologia Britannica, containing The mosses of Great Britain and Ireland, systematically arranged and described according to the method of Bruch and Schimper, with illustrative plates: Being a new (third) edition, with many additions and alterations, of The Muscologia Brittanica of Messrs. Hooker and Taylor. Longman, Brown, Green \& Longmans, London, 445 pp.

Zaccara, S., Patiño, J., Convey, P., Vanetti, I. \& Cannone, N. (2020) Multiple colonization and dispersal events hide the early origin and induce a lack of genetic structure of the moss Bryum argenteum in Antarctica. Ecology and Evolution 10: 8959-8975.

https://doi.org/10.1002/ece3.6601 